\title{
Statistical assessment of water quality parameters for pollution source identification in Bektaş Pond (Sinop,Turkey)
}

\author{
Aydin Uncumusaoğlu A. ${ }^{*}$ \\ Giresun University, Faculty of Engineering, Giresun, 28200, Turkey \\ Received: 26/05/2017, Accepted: 25/08/2017, Available online: 29/01/2018 \\ *to whom all correspondence should be addressed: e-mail: arzu.a.uncumusaoglu@gmail.com
}

\begin{abstract}
This study was carried out between September 2015 and August 2016 in four sampling sites. Water quality of the pond was examined according to sites and seasons, water quality classes were determined and pollution problems were revealed. In addition, the suitability of aquatic life forms has been determined. For these purposes, 21 physico-chemical and seven heavy metal parameters were investigated in the pond water. Pearson correlation, hierarchical cluster analysis, and principal component analysis were applied to test the relationships of all parameters and pollutant loads. According to the analysis results, the main pollution source may be non-point pollution, that is, agricultural pollution and soil leaching for this region. In future freshwater management, these temporal and spatial scale results indicate that watermonitoring schemes need to be scaled-sensitive to water management.
\end{abstract}

Key words: Hierarchical cluster analysis (HCA), principal components analysis (PCA), water quality.

\section{Introduction}

Water is the most valuable natural source; it is the fundamental need of all of the organisms, plants, animals, and humans. Water is the most necessary factor for agriculture, industry, tourism, small companies, and aquaculture.

As a result of the factors such as the increase in the human population and economic activities, domestic and industrial wastes, climate changes, and inability to raise environmental awareness among the society, the water sources are gradually degraded and polluted.

The decrease in quality and amount of surface waters is a result of the unsuccessful management of water pollution and actual water sources. As well as many of them are in developing countries, many regions suffer from unplanned and unbalanced urbanization, excessive agricultural activities, and industrial development. This leads the wastes, sewages, and agricultural leakages to pour into surface waters.

The quality of surface water is an irreplaceable element of the aquatic ecosystem, and it is an important problem nowadays. The deterioration in water quality negatively affects the lives of human, animals, and plants in shortterm, as well as it has many other negative effects in longterm. For this reason, it is very important to determine the pollution in any region. The polluted waters do never constitute a balanced ecosystem.

Water quality is determined by using physicochemical and biological parameters. The polluted surface, in addition, underground waters make it difficult to protect the balanced ecosystem. A balanced ecosystem is a system, where the organisms and environmental factors reciprocally influence each other. Since the water is the most important common element for all of the components of this system, water quality is the most important factor for a balanced aquatic ecosystem.

In western Black Sea region, sewages of residential areas, chemical pesticides and fertilizers used in agriculture, industrial wastes, and geothermal wastes constitute the pollution sources and gradually decrease the quality of surface water in the basin (Egemen, 2006).

For this reason, the properties of lakes and ponds fed by the surface waters, meeting the water requirement of agricultural lands, located within the state hunting area, and being very important recreational areas for their surroundings should be well-known and their ecological balance should be maintained. In order to take the required measures and to determine the pollutants, it is necessary to periodically analyze the physical, chemical, and heavy metal characteristics of the aquatic environments.

Among the multivariate statistical techniques, the hierarchical cluster analysis (HCA) and principal components analysis (PCA) are mainly used in water quality studies. In cluster analysis, the data cluster is divided into groups in terms of the similarities and differences, and the dimensionality of a data cluster is degraded to a new variable group via the principal components analysis. Degradation creates new related variables, and the principal components are ordered according to their importance in order to explain the variance of all the original properties. Many researchers widely apply HCA and PCA analyses in order to classify the water quality 
systems, to monitor the time-based changes in water systems, and to obtain useful findings.

The aim of this study is to determine the changes in some physical and chemical properties and heavy metal concentrations of the water samples taken from 4 stations representing the whole pond between September 2015 and August 2016, to reveal the water quality properties, to better determine the pollution level and pollutants via statistical methods, to enable monitoring these pollutants in further studies, and to make recommendations about taking required measures.

Moreover, another aim of this study is to determine the water quality criteria of Bektaş Pond according to WHO and Inland Water Source Classes of Surface Water Quality Management Regulation (SWQMR). Thus, as well as an important database would be created for future studies to be carried out on this freshwater source, where no study has been carried out before, an important step would be taken in order to protect the pond.

\section{Materials and Methods}

\subsection{Sample location and sampling}

Bektaş Pond is located in Sinop city; northern of Turkey, it is $25 \mathrm{~km}$ away to Sinop, has 300 ha surface area. This pond is the largest of the four ponds located in the town of Boyabat. The eastern, western and northeastern parts of the pond are forested areas. The surround of the pond is one of the important recreational areas of the region. In the pond, there are Cyprinus carpio (carp) and Silurus glanis (catfish) fishes (URL, 2014). The pond is closed to commercial fishing is only open to amateur fishing.

In this study, the sampling sites were determined based on the factors such as the heading hydrological condition, the distance to the streams, and the ease of sampling (Table 1, Figure 1).

Table 1. Coordinates of sampling sites

\begin{tabular}{ccc}
\hline Sampling sites & Latitude & Longitude \\
\hline $\mathrm{S} 1$ & $41^{\circ} 33^{\prime} 09.75^{\prime \prime} \mathrm{N}$ & $34^{\circ} 46^{\prime} 27.78^{\prime \prime} \mathrm{E}$ \\
\hline $\mathrm{S} 2$ & $41^{\circ} 33^{\prime} 04.71^{\prime \prime} \mathrm{N}$ & $34^{\circ} 46^{\prime} 10.35^{\prime \prime} \mathrm{E}$ \\
\hline $\mathrm{S} 3$ & $41^{\circ} 32^{\prime} 53.69^{\prime \prime} \mathrm{N}$ & $34^{\circ} 46^{\prime} 23.64^{\prime \prime} \mathrm{E}$ \\
\hline $\mathrm{S} 4$ & $41^{\circ} 32^{\prime} 53.86^{\prime \prime} \mathrm{N}$ & $34^{\circ} 46^{\prime} 13.81^{\prime \prime} \mathrm{E}$
\end{tabular}

The region of Bektaş pond's climate is warm and temperate, where has a significant amount of rainfall during the year. This is true even for the driest month. The average annual temperature and rainfall are $12.9^{\circ} \mathrm{C}$ and $620 \mathrm{~mm}$. The driest month is July $\left(21.7^{\circ} \mathrm{C}\right)$, with $30 \mathrm{~mm}$ of rainfall. With an average of $75 \mathrm{~mm}$, the most precipitation falls in December the lowest average temperature of the year. It is January $\left(4.0^{\circ} \mathrm{C}\right)$. During the year, the average temperatures vary by $17.7^{\circ} \mathrm{C}$.

The water samples were performed monthly (September 2015 -August 2016) from four sampling stations located on the pond. In all samples, for 28 parameters of water quality were collected in $2.5 \mathrm{~L}$ plastic bottles. For the analysis of water samples, heavy metals were collected in 1-liter precleaned (with $50 \% \mathrm{HNO}_{3}$ and then thrice with deionized water) polyethylene bottles and acidified with $10 \mathrm{ml}$ concentrated $\mathrm{HNO}_{3}$ per liter of wastewater.

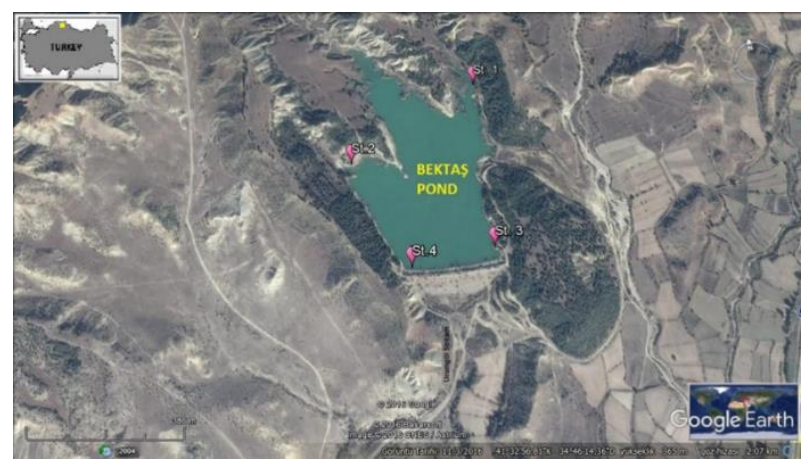

Figure 1. Map of study area with sampling point locations.

\subsection{Determination of physicochemical parameters}

Among the physical parameters of water quality; dissolved oxygen (DO), electrical conductivity (EC), salinity and water temperature (WT) were measured on-site using YSI 556 MPS model multi-meter. Other water quality parameters such as biological oxygen demand (BOD), total hardness $(T H)$, total alkalinity (TA), chemical oxygen demand (COD), phosphate-phosphorus $\left(\mathrm{PO}_{4}^{-3}-\mathrm{P}\right)$, nitrite-nitrogen $\left(\mathrm{NO}_{2}{ }^{-}-\mathrm{N}\right)$, nitrate-nitrogen $\left(\mathrm{NO}_{3}{ }^{-}-\mathrm{N}\right)$, ammonium-nitrogen $\left(\mathrm{NH}_{4}{ }^{+}-\mathrm{N}\right)$, chloride $\left(\mathrm{Cl}^{-}\right)$, sulfite $\left(\mathrm{SO}_{3}{ }^{-2}\right)$, sulfate $\left(\mathrm{SO}_{4}{ }^{-2}\right)$, magnesium $\left(\mathrm{Mg}^{+2}\right)$, calcium $\left(\mathrm{Ca}^{+2}\right)$, sodium $\left(\mathrm{Na}^{+1}\right)$, potassium $\left(\mathrm{K}^{+}\right)$was analyzed in a laboratory using standard method (APHA AWWA WPCF,1995; Anonymous, 1998). The analyses of cadmium $\left(\mathrm{Cd}^{+2}\right)$, nickel $\left(\mathrm{Ni}^{+2}\right)$, ferrous $\left(\mathrm{Fe}^{+2}\right)$, lead $\left(\mathrm{Pb}^{+2}\right)$, copper $\left(\mathrm{Cu}^{+2}\right)$ and zinc $\left(\mathrm{Zn}^{+2}\right)$ water samples were conducted by ICP-MS device in the laboratory.

The creation of the calibration curve was carried out using a certified multi-element standard. For samples were made in triplicate and each parallel was analyzed by ICP-MS instrument 10 readings. Blank samples were prepared with $1 \% \mathrm{HNO}_{3}$ solution 20 times and 3 times with a standard curve obtained and LOD (limit of detection) and 10 times the LOQ (detection limit) is determined (Şengül, 2016).

\subsection{Data treatment and multivariate statistical Analysis}

SPSS statistical package software was utilized for the statistical analysis of water analysis results. Descriptive statistical analysis, including One-way ANOVA, significance (0.01 and 0.05) was done for the stations and seasonal. Important differences in the mean values were tested with Tukey's multiple range tests. On account of add to the nonnormal distribution of measured water quality parameters, the correlation structure between variables was used as a nonparametric measure of the correlation between the Pearson's correlation ( $r$ ) coefficient and the variables calculated over the ranked data (Wunderlin et al., 2001).

Additionally, multivariate analysis of the pond water quality data set was performed through Hierarchical Cluster Analysis (HCA) techniques (Singh et al., 2004; Shrestha and Kazama, 2007; Wu et al., 2010). The HCA used Ward's method as a measure of similarity (Zhaoa et al., 2012; Omo-Irabor et al., 2008). Hierarchical cluster analysis (HCA) is a combination of techniques for classifying large 
datasets into similarities or clusters based on differences. PCA analysis is commonly used to assess spatial and temporal variations in water quality (Ouyang, 2005; Yang et al., 2010; Bu et al., 2010). Before the PCA, KaiserMeyer-Olkin (KMO) and Bartlett's test were performed. In this study, KMO's adequacy is 0.741 for Bektaş Pond. The Bartlett's test $(P=0)$ would indicate that variables are unrelated. Analytical data were analyzed using CA and PCA performed with standardized experimental image data for Z-scale transformation in order to avoid misclassification due to wide differences in data densities (Güler et al., 2002; Singh et al., 2004; Ogwueleka, 2015; Mutlu and Aydin Uncumusaoglu, 2017).

\section{Result and Discussion}

\subsection{Water quality evaluation}

The basic statistics of the pond water quality are summarized in Table 2, which shows the range, mean and standard deviation of each of the 28 parameters, based on 768 total water samples (4 sampling sites, 12 months). The results and the sites where the ranges are located on that showed the DO concentration varied from 9.64 to $13.92 \mathrm{mg}$ $\mathrm{L}^{-1}$, the salinity values ranged from 0.005 to $0.09(\%)$, the $\mathrm{pH}$ values changed from 8.23 to 8.73 , the WT values recorded between 3.1 and $22.8 \mathrm{C}^{\circ}$, the EC values varied from 179.24 to $335.36 \mu \mathrm{S} \mathrm{cm}^{-1}$, the SS values ranged from 1.1 to $4.56 \mathrm{mg} \mathrm{L}^{-1}$, the COD values varied from 1.02 to 3.42 $\mathrm{mg} \mathrm{L}^{-1}$, the $\mathrm{BOD}_{5}$ values recorded between 0.44 and 1.66 $\mathrm{mg} \mathrm{L}^{-1}$, the $\mathrm{Cl}^{-}$concentrations ranged from 3.46 to 6.76 $\mathrm{mg} \mathrm{L}^{-1}$, The $\mathrm{PO}_{4}{ }^{3-}$ concentrations varied from 0.128 to 0.688 $\mathrm{mg} \mathrm{L}^{-1}$, the $\mathrm{SO}_{4}{ }^{2-}$ concentrations recorded between 38.12 and $83.58 \mathrm{mg} \mathrm{L}^{-1}$, the $\mathrm{SO}_{3}{ }^{2-}$ concentrations ranged from 0.42 to $2.78 \mathrm{mg} \mathrm{L}^{-1}$, the $\mathrm{Na}^{+}$concentrations varied from 40.23 to $77.42 \mathrm{mg} \mathrm{L}^{-1}$, the $\mathrm{K}^{+}$concentrations recorded between 3.4 and $16.76 \mathrm{mg} \mathrm{L}^{-1}$, the $\mathrm{TH}$ concentrations ranged from 197.7 to $262.8 \mathrm{CaCO}_{3} \mathrm{mg} \mathrm{L}^{-1}$, the TA concentrations varied from 202.4 to $265.1 \mathrm{CaCO}_{3} \mathrm{mg} \mathrm{L}^{-1}$, the $\mathrm{Mg}^{2+}$ concentrations recorded between 19.70 and $49.34 \mu \mathrm{g} \mathrm{L}^{-1}$, the $\mathrm{Ca}^{2+}$ concentrations ranged from 21.06 to $75.38 \mathrm{\mu gL}^{-1}$, the $\mathrm{NO}^{2-}$ concentrations varied from 0.0001 to $0.0049 \mu \mathrm{g} \mathrm{L}^{-1}$, the $\mathrm{NO}^{3-}$ concentrations recorded between 0.52 and $4.46 \mu \mathrm{g} \mathrm{L}^{-1}$, the $\mathrm{NH}^{4+}$ concentrations ranged from 0 to $0.0022 \mu \mathrm{g} \mathrm{L}^{-1}$, the $\mathrm{Fe}^{2+}$ concentrations varied from 0 to $0.008 \mu \mathrm{g} \mathrm{L}^{-1}$, the $\mathrm{Pb}^{2+}$ concentrations recorded between 0.20 and $2.20 \mu \mathrm{g} \mathrm{L}^{-1}$, the $\mathrm{Cu}^{2+}$ concentrations ranged from 0 to $15 \mu \mathrm{g} \mathrm{L}^{-1}$, the $\mathrm{Cd}^{2+}$ concentrations varied from 0 to 0.4 $\mu \mathrm{g} \mathrm{L}^{-1}$, the $\mathrm{Hg}^{2+}$ concentrations recorded between 0 and $0.008 \mu \mathrm{g} \mathrm{L}^{-1}$, The $\mathrm{Ni}^{2+}$ concentrations varied from 0 to 5

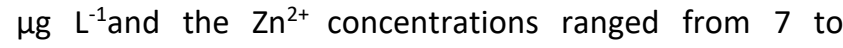
$21 \mu \mathrm{g} \mathrm{L}-1$ (Table 2).

The seasons mean values, standard deviation and minimum -maximum values and the results of all parameters according to the classification system (SWQMR) and guidelines for drinking-water quality (WHO, 2011) are shown in Table 2.

No significant change was observed in the ANOVA test $(P>0.05)$ for the variables measured about sampling sites. Statistically significant differences were found between the seasonal averages according to the ANOVA test $(P<0.05)$ (Table 2).

Pearson's correlation coefficient ( $r$ ) obtained reflect both spatial and temporal changes (Table 3 ). Table 3 presents the values of Pearson's correlation coefficient $(P<0.01$; $P<0.05)$ for pairs of variables at all sampling sites. The importance of water temperature, which is of great importance in terms of water creatures and aquatic ecosystems, is not debatable in terms of climate change. Therefore, it would be appropriate to examine in detail the relationship between water temperature and other parameters. This parameter is a high positive significant $(r \geq 0.750)$ relationship at $P<0.01$ and $P<0.05$ are salinity $(r=0.844), p H(r=0.938), E C(r=0.914)$, SS $(r=0.842)$, COD $(r=0.766), \mathrm{BOD}_{5}(r=0.990), \mathrm{Mg}^{2+}(r=0.893), \mathrm{NO}_{3}{ }^{-}(r=0.974)$, $\mathrm{NH}_{4}{ }^{+}(r=0.823)$, and negative significant relationship with DO ( $r=-0.780$ ) (Table 3).

The $\mathrm{pH}$ of the pond was determined to be the class (II-III) according to SWQMR, which means it is polluted water (SWQMR, 2015). Also, according to WHO standards; the maximum limit has been exceeded. It is indisputable that $\mathrm{pH}$ carries a risk for their when we think it is important for delicate water creatures, because of the mild alkali character of the Bektaş pond. $\mathrm{pH}$ has a high positive significant $(r \geq 0.750)$ relationship at $P<0.01$ and $P<0.05$ are WT( $r=0.980)$, salinity $(r=0.804), E C(r=0.831), S S(r=0.772)$, $\mathrm{BOD}_{5}(r=0.923), \mathrm{TH}(\mathrm{r}=0.761), \mathrm{TA}(\mathrm{r}=0.765), \mathrm{Mg}^{2+}(\mathrm{r}=0.787)$, $\mathrm{NO}_{3}{ }^{-}(r=0.886), \mathrm{NH}_{4}{ }^{+}(r=0.771), \mathrm{Hg}^{2+}(r=0.790)$ and negative significant relationship with DO ( $r=-0.750)$ (Table 3$)$.

According to SWQMR, some phosphate values have exceeded acceptable limits (Class II-IV), which means it is polluted water (SWQMR, 2015). It is thought that the fertilizer used in agriculture is the result of fertilizing the environment as a source of phosphate fertilization. $\mathrm{PO}_{4}$ has a high positive significant $(r \geq 0.750)$ relationship at $P<0.01$ and $P<0.05$ is positively associated with all heavy metals except lead. Additionally, it has a weak negative correlation with $\mathrm{SO}_{4}{ }^{2-}$ and $\mathrm{SO}_{3}{ }^{2-}$ (Table 3 ).

The main source of sulphate and sulphite in the water is gypsum, anhydrite, and fertilizers used for agricultural activities. The $\mathrm{SO}_{3}{ }^{2-}$ of the pond was determined to be class (I-III) according to SWQMR, which means it is almost polluted water (SWQMR, 2015). The other parameters that this parameter may affect; $\mathrm{SO}_{4}{ }^{2-}(r=0.961), \mathrm{Na}^{+}(r=0.936)$, $\mathrm{Ca}^{2+}(r=0.763), \mathrm{NO}_{2}^{-}(r=0.768), \mathrm{Cu}^{2+}(r=0.772)(P<0.01$ and $\mathrm{P}<0.05$ ) (Table 3). 
Table 2. Seasonal Mean. Standard deviation (SD), range (Mean \pm SD; Minimum (Site) - maximum (Site)), WHO limit and Class (SWMQR, 2015) of water quality parameters

\begin{tabular}{|c|c|c|c|c|c|c|c|}
\hline & Winter & Spring & Summer & Autumn & Range (Site) & WHO & $\begin{array}{c}\text { Class } \\
\text { (SWQMR) }\end{array}$ \\
\hline \multirow{2}{*}{$\mathrm{DO}\left(\mathrm{mg} \mathrm{L}^{-1}\right)$} & $13.195 \pm 0.304^{c}$ & $13.583 \pm 0.365^{c}$ & $11.845 \pm 1.376^{\mathbf{b}}$ & $10.275 \pm 0.773^{\mathrm{a}}$ & $12.225 \pm 1.534$ & & \multirow{2}{*}{ 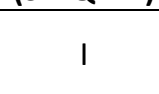 } \\
\hline & $12.91-13.67$ & $13.08-13.92$ & $10.78-13.72$ & 9.64-11.34 & $9.64(1)-13.92(4)$ & & \\
\hline \multirow{2}{*}{ Salinity(\%o) } & $0.016 \pm 0.009^{a}$ & $0.015 \pm 0.007^{a}$ & $0.037 \pm 0.020^{b}$ & $0.066 \pm 0.022^{c}$ & $0.033 \pm 0.026$ & & \\
\hline & 0.01-0.03 & 0.01-0.03 & 0.005-0.07 & 0.03-0.09 & $0.005(1)-0.09(1,2)$ & & \\
\hline \multirow{2}{*}{ pH } & $8.291 \pm 0.040^{a}$ & $8.432 \pm 0.045^{b}$ & $8.571 \pm 0.064^{c}$ & $8.590 \pm 0.146^{c}$ & $8.471 \pm 0.147$ & \multirow{2}{*}{$6.5-8.5$} & \multirow{2}{*}{ II-III } \\
\hline & 8.23-8.33 & $8.36-8.49$ & 8.48-8.64 & $8.38-8.73$ & $8.23(2,4)-8.73(1)$ & & \\
\hline \multirow{2}{*}{ WT $\left(C^{\circ}\right)$} & $5.342 \pm 2.152^{\mathrm{a}}$ & $9.692 \pm 3.391^{b}$ & $17.208 \pm 1.838^{c}$ & $20.158 \pm 3.518^{c}$ & $13.10 \pm 6.544$ & & \multirow[b]{2}{*}{1} \\
\hline & $3.1-8.7$ & 5.7-13.8 & $14.8-19.3$ & $15.2-22.8$ & $3.1(3,4)-22.8(1)$ & & \\
\hline \multirow{2}{*}{$\mathrm{EC}(\mu \mathrm{S} \mathrm{cm}-1)$} & $216.86 \pm 15.68^{a}$ & $202.23 \pm 16.53^{\mathrm{a}}$ & $301.6 \pm 16.174^{b}$ & $310.9 \pm 31.069^{b}$ & $257.9 \pm 53.24$ & \multirow{2}{*}{1500.0} & \multirow[b]{2}{*}{1} \\
\hline & $202.84-238.96$ & $179.24-217.74$ & $282.6-324.14$ & $266.34-335.36$ & $179.24(3)-335.36(1)$ & & \\
\hline \multirow{2}{*}{$S S\left(\mathrm{mg} \mathrm{L}^{-1}\right)$} & $1.537 \pm 0.304^{\mathrm{a}}$ & $1.293 \pm 0.165^{a}$ & $2.523 \pm 0.673^{b}$ & $3.842 \pm 0.756^{c}$ & $2.299 \pm 1.138$ & & \\
\hline & $1.28-2.04$ & 1.1-1.52 & 1.9-3.46 & $2.8-4.56$ & $1.1(4)-4.56(1)$ & & \\
\hline \multirow{2}{*}{$\operatorname{COD}\left(\mathrm{mg} \mathrm{L}^{-1}\right)$} & $1.301 \pm 0.390^{\mathrm{a}}$ & $1.805 \pm 0.390^{b}$ & $2.647 \pm 0.545^{c}$ & $2.483 \pm 0.088^{c}$ & $2.059 \pm 0.663$ & \multirow[b]{2}{*}{10.0} & \multirow[b]{2}{*}{1} \\
\hline & $1.02-1.96$ & $1.4-2.34$ & $2.2-3.42$ & $2.38-2.66$ & $1.02(2,3,4)-3.42(1)$ & & \\
\hline \multirow{2}{*}{$\mathrm{BOD}_{5}\left(\mathrm{mg} \mathrm{L}^{-1}\right)$} & $0.550 \pm 0.129^{a}$ & $0.775 \pm 0.194^{b}$ & $1.332 \pm 0.071^{\mathrm{c}}$ & $1.427 \pm 0.225^{c}$ & $1.021 \pm 0.406$ & & \multirow{2}{*}{1} \\
\hline & $0.44-0.78$ & $0.54-1.06$ & $1.22-1.42$ & 1.1-1.66 & $0.44(4)-1.66(1)$ & & \\
\hline \multirow{2}{*}{$\mathrm{Cl}^{-}\left(\mathrm{mgL}^{-1}\right)$} & $4.701 \pm 1.298^{\mathrm{a}}$ & $4.777 \pm 0.66^{\mathrm{a}}$ & $6.087 \pm 0.207^{b}$ & $5.963 \pm 0.558^{b}$ & $5.382 \pm 1.002$ & \multirow{2}{*}{250.0} & \multirow[b]{2}{*}{1} \\
\hline & $3.46-6.76$ & $3.88-5.46$ & $5.8-6.34$ & 5.14-6.4 & $3.46(1)-6.76(2)$ & & \\
\hline \multirow{2}{*}{$\mathrm{PO}_{4}{ }^{3-}\left(\mathrm{mgL}^{-1}\right)$} & $0.241 \pm 0.114^{\mathrm{a}}$ & $0.213 \pm 0.020^{\mathrm{a}}$ & $0.161 \pm 0.014^{\mathrm{a}}$ & $0.426 \pm 0.236^{b}$ & $0.260 \pm 0.162$ & & \multirow{2}{*}{ II-IV } \\
\hline & $0.144-0.54$ & $0.19-0.244$ & $0.138-0.178$ & $0.128-0.688$ & $0.128(4)-0.688(1)$ & & \\
\hline \multirow{2}{*}{$\mathrm{SO}_{4}^{2-}\left(\mathrm{mgL}^{-1}\right)$} & $45.37 \pm 10.20^{\mathrm{a}}$ & $64.92 \pm 10.41^{b}$ & $71.43 \pm 8.59^{b}$ & $50.90 \pm 6.59^{a}$ & $58.16 \pm 13.75$ & \multirow{2}{*}{250.0} & \\
\hline & $38.12-59.78$ & $52.88-78.16$ & $61.86-83.58$ & $42.32-59.88$ & $38.12(3)-83.58(1)$ & & \\
\hline \multirow{2}{*}{$\mathrm{SO}_{3}^{-2}\left(\mathrm{mgL}^{-1}\right)$} & $0.730 \pm 0.359^{a}$ & $1.693 \pm 0.440^{b}$ & $2.055 \pm 0.636^{\mathbf{b}}$ & $0.897 \pm 0.175^{a}$ & $1.344 \pm 0.696$ & & \multirow{2}{*}{$|-| I \mid$} \\
\hline & $0.42-1.24$ & $1.08-2.12$ & $1.22-2.78$ & $0.68-1.16$ & $0.42(4)-2.78(1)$ & & \\
\hline \multirow{2}{*}{$\mathrm{Na}^{+}\left(\mathrm{mgL}^{-1}\right)$} & $45.183 \pm 3.892^{a}$ & $60.275 \pm 11.61^{b}$ & $62.728 \pm 12.92^{b}$ & $41.297 \pm 0.624^{\mathrm{a}}$ & $52.371 \pm 12.73$ & & \\
\hline & $40.23-50.38$ & $46.96-74.82$ & 46.96-77.42 & $40.48-42.04$ & $40.23(4)-77.42(3)$ & 200.0 & \\
\hline & $6.465 \pm 2.162^{\mathrm{ab}}$ & $7.827 \pm 1.842^{\mathrm{bc}}$ & $9.738 \pm 4.942^{c}$ & $4.245 \pm 0.963^{\mathrm{a}}$ & $7.069 \pm 3.452$ & & \\
\hline $\mathrm{K}^{+}\left(\mathrm{mgL}^{-1}\right)$ & $3.68-9.08$ & $6.42-10.42$ & $6.02-16.76$ & $3.4-5.56$ & $3.4(3)-16.76(2)$ & 12.0 & \\
\hline & $212.27 \pm 13.03^{a}$ & $220.08 \pm 9.62^{a}$ & $251.58 \pm 3.64^{c}$ & $237.22 \pm 19.75^{b}$ & $230.29 \pm 19.83$ & & \\
\hline TH $\left(\mathrm{mgL}^{-1}\right)$ & $197.74-228.9$ & $210.12-233.02$ & $246.2-256.06$ & $213.26-262.84$ & $197.7(3)-262.8(4)$ & & \\
\hline & $217.08 \pm 13.24^{\mathrm{a}}$ & $224.98 \pm 8.90^{\mathrm{a}}$ & $256.67 \pm 4.74^{c}$ & $241.88 \pm 18.57^{b}$ & $235.15 \pm 19.62$ & & \\
\hline TA $\left(\mathrm{mgL}^{-1}\right)$ & $202.42-234.98$ & $215.28-238.16$ & $250.18-261.66$ & $219.46-265.1$ & $202.4(3)-265.1(4)$ & 200 & \\
\hline & $24.41 \pm 7.49^{a}$ & $24.68 \pm 3.97^{a}$ & $43.77 \pm 5.11^{b}$ & $42.12 \pm 2.49^{b}$ & $33.74 \pm 10.55$ & & \\
\hline $\mathrm{Mg}^{2+}\left(\mathrm{mgL}^{-1}\right)$ & $19.70-36.82$ & $21.02-30.48$ & $37.02-49.34$ & $39.06-44.98$ & $19.70(1)-49.34(2)$ & 50 & \\
\hline & $25.65 \pm 7.72^{\mathrm{a}}$ & $42.16 \pm 12.48^{b}$ & $56.89 \pm 11.79^{c}$ & $43.50 \pm 2.69^{b}$ & $42.05 \pm 14.49$ & & \\
\hline $\mathrm{Ca}^{2+}\left(\mathrm{mgL}^{-1}\right)$ & $21.06-38.76$ & $29.22-58.42$ & $46.16-75.38$ & $39.82-46.7$ & $21.06(1)-75.38(1)$ & 300 & \\
\hline
\end{tabular}




\begin{tabular}{|c|c|c|c|c|c|c|c|}
\hline & Winter & Spring & Summer & Autumn & Range (Site) & WHO & $\begin{array}{c}\text { Class } \\
\text { (SWQMR) }\end{array}$ \\
\hline $\mathrm{NO}_{2}^{-}\left(\mathrm{mgL}^{-1}\right)$ & $\begin{array}{c}0.004 \pm 0.0008^{a} \\
0.0001-0.003\end{array}$ & $\begin{array}{c}0.015 \pm 0.001^{a} \\
0.0-0.003\end{array}$ & $\begin{array}{l}0.0029 \pm 0.001^{b} \\
0.0010-0,0049\end{array}$ & $\begin{array}{c}0.0012 \pm 0.001^{\mathrm{a}} \\
0.0004-0.004\end{array}$ & $\begin{array}{c}0.0015 \pm 0.001 \\
0.0001(1,2,3,4)- \\
0.0049(1)\end{array}$ & & 1 \\
\hline $\mathrm{NO}_{3}^{-}\left(\mathrm{mgL}^{-1}\right)$ & $\begin{array}{c}1.008 \pm 0.475^{a} \\
0.52-1.76 \\
\end{array}$ & $\begin{array}{c}1.777 \pm 0.689^{b} \\
1-2.66 \\
\end{array}$ & $\begin{array}{c}3.835 \pm 0.464^{c} \\
3.2-4.34 \\
\end{array}$ & $\begin{array}{c}3.898 \pm 0.428^{c} \\
3.4-4.46 \\
\end{array}$ & $\begin{array}{c}2.630 \pm 1.377 \\
0.52(4)-4.46(1) \\
\end{array}$ & 50 & I \\
\hline $\mathrm{NH}_{4}{ }^{+}\left(\mathrm{mgL}^{-1}\right)$ & $\begin{array}{c}0.0 \pm 0.001^{\mathrm{a}} \\
0-0.002 \\
\end{array}$ & $\begin{array}{c}0.0 \pm 0.0^{\mathrm{a}} \\
0.0001-0.0005 \\
\end{array}$ & $\begin{array}{c}0.001 \pm 0^{\mathrm{b}} \\
0.0005-0.0018 \\
\end{array}$ & $\begin{array}{c}0.002 \pm 0^{c} \\
0.001-0.0022 \\
\end{array}$ & $\begin{array}{c}0.0001 \pm 0.001 \\
0(1,4)-0.0022(1)\end{array}$ & 35 & I \\
\hline $\mathrm{Fe}^{2+}\left(\mathrm{mg} / \mathrm{L}^{-1}\right)$ & $\begin{array}{c}0 \pm 0^{\mathrm{a}} \\
0-0.001 \\
\end{array}$ & $\begin{array}{c}0.001 \pm 0.001^{\mathrm{ab}} \\
0-0.002 \\
\end{array}$ & $\begin{array}{c}0.001 \pm 0.001^{b c} \\
0.001-0.003 \\
\end{array}$ & $\begin{array}{c}0.002 \pm 0.002^{c} \\
0.001-0.008 \\
\end{array}$ & $\begin{array}{c}0.001 \pm 0.001 \\
0(1,2,3,4)-0.008(1) \\
\end{array}$ & 0.300 & 1 \\
\hline $\mathrm{Pb}^{2+}\left(\mu \mathrm{g} / \mathrm{L}^{-1}\right)$ & $\begin{array}{c}0.85 \pm 0.14^{\mathrm{ab}} \\
0.60-1.10 \\
\end{array}$ & $\begin{array}{c}1.35 \pm 0.37^{\mathrm{c}} \\
1-2 \\
\end{array}$ & $\begin{array}{c}1.27 \pm 0.62^{\mathrm{bc}} \\
0.60-2.20 \\
\end{array}$ & $\begin{array}{c}0.70 \pm 0.33^{\mathrm{a}} \\
0.20-1.10 \\
\end{array}$ & $\begin{array}{c}1.04 \pm 0.48 \\
0.20(4)-2.20(2) \\
\end{array}$ & 0.010 & 1 \\
\hline $\mathrm{Cu}^{2+}\left(\mu \mathrm{g} / \mathrm{L}^{-1}\right)$ & $\begin{array}{c}2.167 \pm 1.749^{a} \\
0-4.0 \\
\end{array}$ & $\begin{array}{c}5.417 \pm 4.274^{\mathrm{ab}} \\
0-11.0 \\
\end{array}$ & $\begin{array}{c}8.417 \pm 3.825^{b} \\
4.0-15.0 \\
\end{array}$ & $\begin{array}{c}5.667 \pm 1.435^{b} \\
4.0-8.0 \\
\end{array}$ & $\begin{array}{c}5.417 \pm 3.729 \\
0(1,2,3,4)-15(2) \\
\end{array}$ & 2.00 & 1 \\
\hline $\mathrm{Cd}^{2+}\left(\mu \mathrm{g} / \mathrm{L}^{-1}\right)$ & $\begin{array}{c}0.14 \pm 0.124^{a} \\
0-0.3 \\
\end{array}$ & $\begin{array}{c}0.29 \pm 0.029^{b c} \\
0.2-0.3 \\
\end{array}$ & $\begin{array}{c}0.23 \pm 0.098^{\mathrm{ab}} \\
0.1-0.3 \\
\end{array}$ & $\begin{array}{c}0.36 \pm 0.067^{c} \\
0.2-0.4 \\
\end{array}$ & $\begin{array}{c}0.26 \pm 0.117 \\
0(1,2,3,4)-0.4(1,2,3,4)\end{array}$ & & I \\
\hline $\mathrm{Hg}^{2+}\left(\mu \mathrm{g} / \mathrm{L}^{-1}\right)$ & $\begin{array}{c}0.001 \pm 0.002^{\mathrm{a}} \\
0-0.005 \\
\end{array}$ & $\begin{array}{c}0.001 \pm 0.001^{\mathrm{a}} \\
0-0.002 \\
\end{array}$ & $\begin{array}{c}0.003 \pm 0.001^{\mathrm{ab}} \\
0.002-0.005 \\
\end{array}$ & $\begin{array}{l}0.004 \pm 0.003^{c} \\
0.0008-0.008\end{array}$ & $\begin{array}{c}0.002 \pm 0.002 \\
0(1,2,3,4)-0.008(2)\end{array}$ & & 1 \\
\hline $\mathrm{Ni}^{2+}\left(\mu \mathrm{g} / \mathrm{L}^{-1}\right)$ & $\begin{array}{c}1.33 \pm 1.231^{\mathrm{a}} \\
0-3.0\end{array}$ & $\begin{array}{c}2.083 \pm 1.782^{\mathrm{ab}} \\
0-5.0\end{array}$ & $\begin{array}{c}3.00 \pm 0.0^{\text {bc }} \\
0-3.0\end{array}$ & $\begin{array}{c}3.583 \pm 0.90^{c} \\
2.0-3.0\end{array}$ & $\begin{array}{c}2.50 \pm 1.429 \\
0(1,2,3,4)-5(2,3)\end{array}$ & & I \\
\hline $\mathrm{Zn}^{2+}\left(\mu \mathrm{gL}^{-1}\right)$ & $\begin{array}{c}7.66 \pm 0.985^{a} \\
7.0-10.0\end{array}$ & $\begin{array}{c}11.08 \pm 3.288^{\mathrm{ab}} \\
7.0-15.0\end{array}$ & $\begin{array}{c}13.41 \pm 3.029^{b} \\
10.0-18.0\end{array}$ & $\begin{array}{c}13.67 \pm 5.176^{b} \\
8.0-21.0\end{array}$ & $\begin{array}{c}11.46 \pm 4.136 \\
7(1,2,3,4)-21(2,3)\end{array}$ & 0.010 & 1 \\
\hline
\end{tabular}

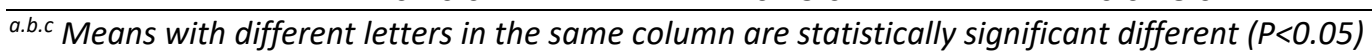


Table 3. Pearson correlation matrix among the variables

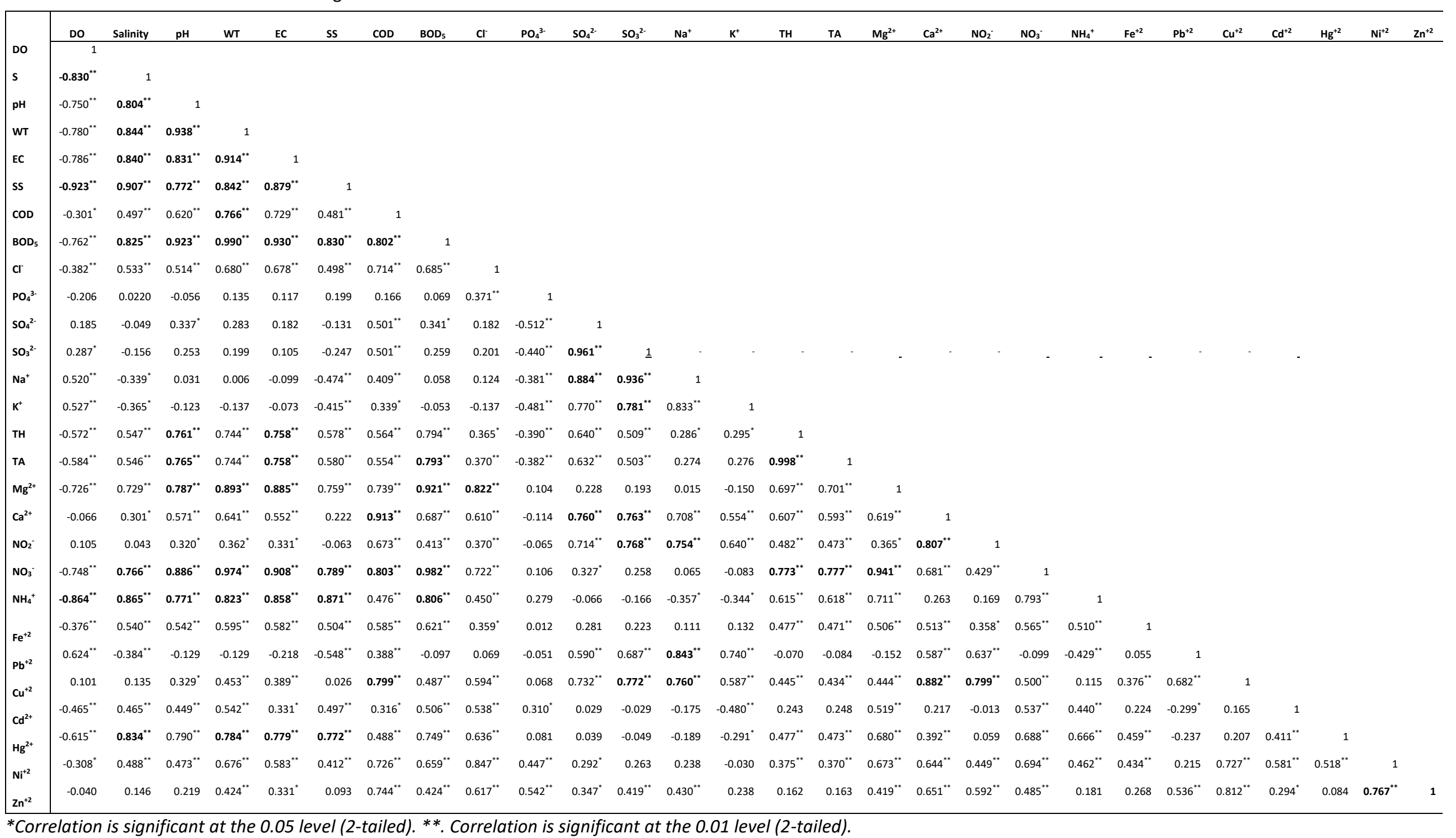




\subsection{Spatial and temporal variation in pond water quality HCA, PCA}

Hierarchical Cluster Analysis was used to identify groups of similarity between sampling areas, which was applied to the data obtained from the monthly samples from four sites. The best results for the variable relationship between the methods used for correlation and distance combination were obtained using Ward's method and Euclidean distance.

In the Bektaş pond, Cluster 1 includes Site 4 . This cluster is represented by only one site because the Urumgöl Stream (freshwater discharge) is the main source of both the feeding pond and the pollution load (Figure 1). Cluster 2 includes Site 1 and Sites 2, 3. Site 1 is the farthest point to the freshwater supply entrance and sites 2, 3 are colocated with the pollution load together. This situation is thought to be related to the distance to the source of pollution. Cluster 3 contains sites 2 and 3 (Figure 2). These sites have the same pollution loads because they are equidistant from the pollution load coming from the pond and precipitation. Similar results have been found when this analysis is applied to water quality parameters

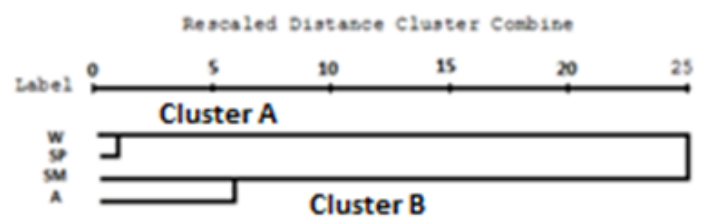

(Simeonov et al. 2003; Coletti et al 2010; Zhang et al., 2011; Özdemir, 2016).

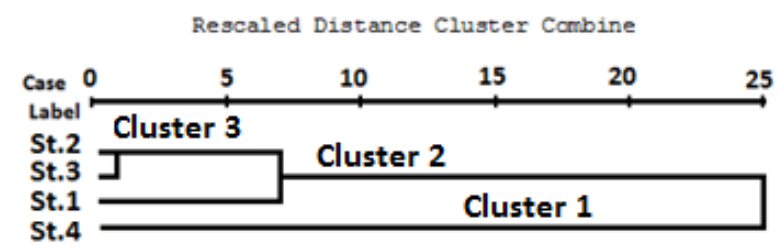

Figure 2. Dendogram (using Ward Method) shows clusters of variables (St.: Site)

According to the results of HCA analysis based on seasonal mean values, the seasonal differences clustered as seen in Figure 3. The Cluster $A$ includes winter and spring. The Cluster B involves summer and autumn. This clustering is also similar to the ANOVA test results. It is seen in Figure 3 that the spring season is the transition period between the clusters in detail (Shrestha and Kazama, 2007; Aydın Uncumusaoğlu et al., 2016).

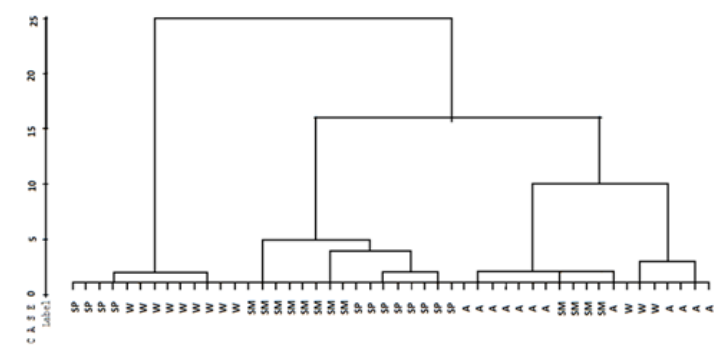

Figure 3. Dendogram (using Ward Method) shows clusters of variables (A: Autumn, Sm:Summer, Sp:Spring and W:Winter)

In PCA analysis contains three components, 28 physicochemical parameters were categorized. PCA's classified the factor loadings as 'strong', 'moderate' and 'weak', matching to absolute loading values of $>0.75,0.75-0.50$ and 0.50-0.30, respectively (Liu et al., 2003). The results of calculations were shown in Table 4. According to Hair et al. (2009), the choice of the number of major components to be retained in the number of major components released before a clear break between scree.

These components were acquired with eigenvalues $>1$ summing $85.58 \%$ of the total variance in the surface water dataset (Table 6). The first PC, explaining $43.52 \%$ of the total variance has strong positive loading on $\mathrm{EC}, \mathrm{BOD}_{5}, \mathrm{WT}$, SS, salinity, $\mathrm{pH}, \mathrm{NH}_{4}^{+}, \mathrm{DO}, \mathrm{Mg}^{2+}$, Total alkalinity, Total hardness, $\mathrm{Hg}^{2+}$ and moderate positive loadings on $\mathrm{Fe}^{2+}$, $\mathrm{COD}, \mathrm{Cd}^{2+}$, and weak positive loadings on $\mathrm{NO}_{2}{ }^{-}, \mathrm{Zn}^{2+}, \mathrm{SO}_{3}{ }^{2-}$, It has negative strong loadings DO and weak loading $\mathrm{Ni}^{2+}$.This factor, in which all parameters with strongly related dissolved oxygen are present, is also contained in $\mathrm{Hg}^{2+}$ which is a very toxic heavy metal (Table 3, 5 and Figure 4). $\mathrm{EC}$ is highly correlated with $\mathrm{SS}, \mathrm{COD}, \mathrm{BOD}_{5}, \mathrm{Cl}, \mathrm{TH}, \mathrm{TA}$, $\mathrm{Mg}^{2+}, \mathrm{NO}_{3}, \mathrm{NH}_{4}, \mathrm{Fe}^{2+}, \mathrm{Hg}^{2+}, \mathrm{Ni}^{2+}$ and $\mathrm{Zn}^{2+}$ as shown in Table 3. PC1's high-load-bearing parameters are also seen in
Pearson correlations, which are highly related to each other (Table 4). In addition, this factor loading can be commented as organic pollution and attributed to the seasonal effect of temperature. This natural source of these parameters in catchments of flowing run-off and soil leaching (Simeonov et al., 2003; Kannel, 2007; Vialle et al., 2011).

The second PC, accounting for $28.39 \%$ of the total variance has strong positive loading on $\mathrm{SO}_{4}{ }^{2-}, \mathrm{Na}^{+}, \mathrm{K}^{+}, \mathrm{Ca}^{2+}, \mathrm{Cu}^{2+}, \mathrm{Pb}^{2+}$, $\mathrm{Zn}^{2+}, \mathrm{Ni}^{2+}$, and positive moderate loadings on $\mathrm{Fe}^{2+}$, total alkalinity, total hardness. It has a negative weak loading $\mathrm{PO}_{4}{ }^{3-}$. This factor indicates the contribution of non-point source pollution from heavy metal and anions originating from soil or rock structure by agricultural runoff and atmospheric deposition and basin geology and soil structure.

The third PC, accounting for $13.67 \%$ of the total variance, has strong positive loading on $\mathrm{PO}_{4}{ }^{3-}, \mathrm{NO}_{2}{ }^{-}, \mathrm{Cl}^{-}$and moderate positive loadings on $\mathrm{Cd}^{2+}$, positive weak loading $\mathrm{Mg}^{2+}, \mathrm{Fe}^{2+}$, $\mathrm{SO}_{3}{ }^{2-}, \mathrm{Pb}^{2+}$. Phosphorus ponds are found because of the transfer of water, soil, and rocks to the pond, where the phosphorus accumulation of rainwater and river deposits is accumulated. This is factor represents the contribution of 
non-point source pollution from agricultural areas by farmers use the nitrogenous fertilizer, which undergoes nitrification processes, and the rivers receive nitrate nitrogen via groundwater leaching (Kazama and Yoneyama, 2002; Mustapha and Nabegu, 2011; Aydin Uncumusaoğlu and Akkan, 2017). There is no industry in the field of work, so only cadmium is the fertilizer source. Since cadmium is the element with the highest water solubility in other heavy metals, the use of pond water for irrigation in agriculture means the inclusion of cadmium in the food chain, which is both at risk for both aquatic life and human health.

Table 4. Varimax rotated factor matrix for the whole data set

\begin{tabular}{|c|c|c|c|}
\hline $\begin{array}{c}\text { Variable } \\
\text { Factor loadings (varimax normalized) }\end{array}$ & PC 1 & PC 2 & PC 3 \\
\hline $\begin{array}{l}\text { Eigenvalues } \\
\end{array}$ & 13.714 & 7.369 & 2.879 \\
\hline Variance (\%) & 43.524 & 28.385 & 13.671 \\
\hline Cumulative (\%) & 43.524 & 71.909 & 85.580 \\
\hline EC & 0.941 & 0.225 & 0.220 \\
\hline $\mathrm{BOD}_{5}$ & 0.936 & 0.158 & 0.262 \\
\hline WT & 0.933 & 0.100 & 0.178 \\
\hline SS & 0.920 & -0.295 & 0.113 \\
\hline pH & 0.917 & 0.163 & 0.029 \\
\hline $\mathrm{NO}_{3}{ }^{-}$ & 0.910 & 0.224 & 0.278 \\
\hline Salinity & 0.886 & -0.198 & 0.178 \\
\hline $\mathrm{NH}_{4}^{+}$ & 0.879 & -0.191 & 0.153 \\
\hline DO & -0.879 & 0.375 & -0.031 \\
\hline $\mathrm{Mg}^{2+}$ & 0.864 & 0.156 & 0.303 \\
\hline TA & 0.814 & 0.437 & -0.262 \\
\hline TH & 0.812 & 0.450 & -0.263 \\
\hline $\mathrm{Hg}^{2+}$ & 0.793 & -0.085 & 0.177 \\
\hline $\mathrm{Fe}^{2+}$ & 0.585 & 0.564 & 0.477 \\
\hline COD & 0.580 & 0.251 & 0.124 \\
\hline $\mathrm{SO}_{3}{ }^{2}$ & 0.479 & -0.157 & 0.434 \\
\hline $\mathrm{SO}_{4}{ }^{2-}$ & -0.174 & 0.967 & 0.014 \\
\hline $\mathrm{Na}^{+}$ & 0.068 & 0.956 & -0.071 \\
\hline $\mathbf{K}^{+}$ & 0.189 & 0.926 & -0.165 \\
\hline $\mathrm{Ca}^{2+}$ & -0.209 & 0.882 & -0.231 \\
\hline $\mathrm{Cu}^{2+}$ & 0.198 & 0.827 & 0.216 \\
\hline $\mathrm{Pb}^{2+}$ & 0.223 & 0.823 & 0.469 \\
\hline $\mathrm{Zn}^{2+}$ & 0.452 & 0.808 & 0.298 \\
\hline $\mathrm{Ni}^{2+}$ & -0.378 & 0.802 & 0.273 \\
\hline $\mathrm{PO}_{4}{ }^{3-}$ & -0.029 & -0.388 & 0.844 \\
\hline $\mathrm{Cl}^{-}$ & 0.139 & 0.483 & 0.796 \\
\hline $\mathrm{NO}_{2}^{-}$ & 0.480 & 0.297 & 0.735 \\
\hline $\mathrm{Cd}^{2+}$ & 0.553 & 0.194 & 0.661 \\
\hline
\end{tabular}

Scree Plot

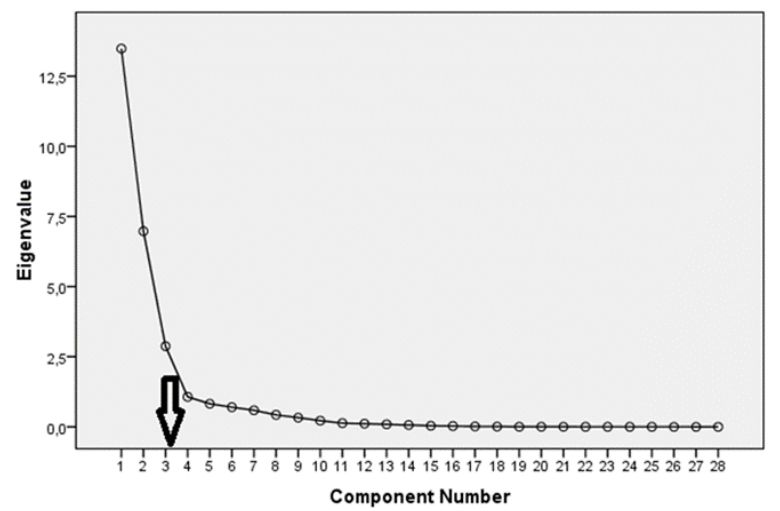

Figure 4. Scree-plot for the principal component model of the monitoring data 


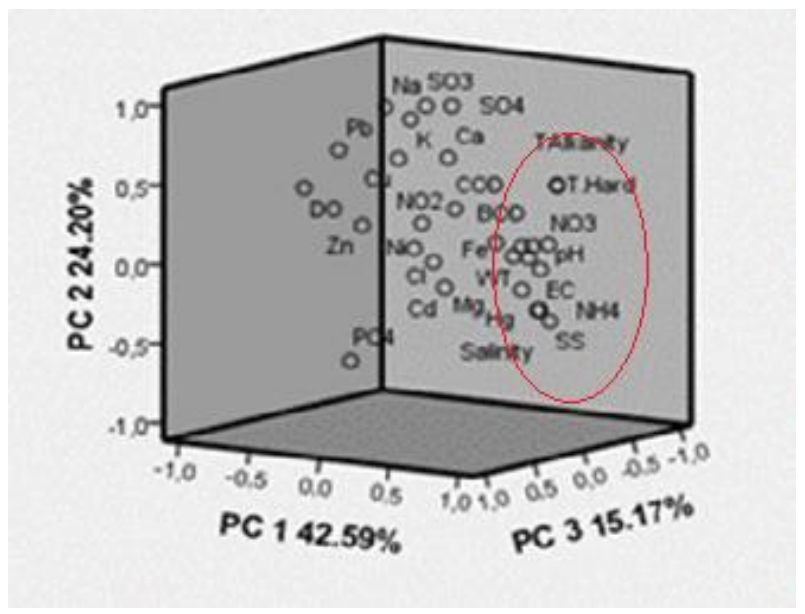

Figure 5. Component plot

\section{Conclusions}

In this study, the water quality data obtained from four different sampling points for 12 months in the Bektaş Pond were analyzed by using multivariate statistical methods to determine the water quality as well as whether it is suitable for the aquatic life. It has been determined that this pond has aquatic life and suitable for their life now. The analyses and statistical tests conducted have resulted in the protection of the pond water only depending on the control of the amount and content of the fertilizers used in agriculture activities and the effect of $\mathrm{pH}$ changes on the aquatic ecosystem due to the sudden temperature changes as a result of changing the climate. A suggested solution to the problems is "best environmental practice" principle should be applied to minimize the out-of-source pollution and to efficiently use and control stocks of freshwater resources.

According to WHO and SWQMR guideline, most of the parameters are clean water quality. Nevertheless, there are some parameters found as contaminated water. In terms of phosphate, sulphite and $\mathrm{pH}$, both the aquatic life and the use of water as drinking water and irrigation water are not the desired characteristics. These parameters are not for the aquatic creatures, nor are the human activities necessary for water quality. In this study, the pond does not carry a risk in terms of heavy metal. The results of all the statistical analyses (ANOVA, Pearson correlation, HCA, and PCA) applied to the parameters are common results. The PCA applied to pond water quality parameters determined the main parameters from three main sources. The result is that the main pollution source of the pond is non-point pollution. According to the result of HCA analysis, there was no significant difference between the stations but has a significant difference between seasons. Measures should be taken according to the WHO and SWQMR guideline, for conservation and improvement of the water quality of the pond (Class I-IV). In future research for the prevention of pollution from agriculture, it is necessary to perform the modeling and regular monitoring should be done. Because of the statistical analysis, it has been learned which parameters should be examined in order to be able to carry out monitoring and this will provide both time and economic benefits in future research.

\section{References}

Anonymous. (1998). Standard methods for the examination of water and wastewater. American Public Health Association, $7^{\text {th }}$ Edition, Washington, USA.

APHA, AWWA, WPCF. (1995). Standard Methods for examination of water and wastewater. 18 th Ed. Washington, USA.

Aydin Uncumusaoğlu A. and Akkan T. (2017), Assessment of water quality of Yağlıdere Stream using multivariate statistical techniques, Polish Journal of Environmental Studies, 26(4), 1715-1723. https://doi.org/10.15244/pjoes/68952

Aydın Uncumusaoğlu A., Sengül U. and Akkan, T. (2016), Environmental contamination of heavy metals in the Yağlıdere Stream (Giresun) Southeastern Black Sea, Fresenius Environmental Bulletin, 25(12), 5492-5498.

Bu H., Tan X., Li S. and Zhang Q. (2010), Water quality assessment of the Jinshui River (China) using multivariate statistical techniques, Environmental Earth Sciences, 60(8), 1631-1639. https://doi.org/10.1007/s12665-009-0297-9

Egemen Ö. (2006), Su kalitesi. Ege Üniversitesi, Su Ürünleri Fakültesi, Yayın No:14, 6.baskı. Bornova/izmir. 150 p.

Güler C., Thyne G.D., Mccray J.E. and Turner K.A. (2002), Evaluation of graphical and multivariate statistical methods for classification of water chemistry data, Hydrogeol. J., 10(4), 455-474.

Hair J.F., Black W.C., Babin B.J. and Anderson R.E. (2009), Multivariate data analysis. Upper Saddle River, NJ: Prentice Hall.

Kannel P.R., Lee S., Kanel S.R. and Khan S.P. (2007), Chemometric application in classification and assessment of monitoring locations of an Urban River System, Analytica Chimica Acta, 582(2), 390-399.

Kazama F. and Yoneyama M. (2002), Nitrogen generation in the Yamanashi prefecture and its effects on the groundwater pollution, International Environmental Science, 15(4), 293-298.

Liu C., Lin K. and Kuo Y. (2003), Application of factor analysis in the assessment of groundwater quality in a Blackfoot Disease area in Taiwan, Science of the Total Environment, 313(1-3), 77-89.

Mustapha A. and Nabegu A.B. (2011), Surface water pollution source identification using principal component analysis and 
factor analysis in Getsi River, Kano, Nigeria, Austr J Basic ApplSci, 5, 1507-1512.

Mutlu E. and Aydın Uncumusaoğlu A. (2016), Physicochemical analysis of water quality of Brook Kuruçay, Turkish Journal of Agriculture, Food Science and Technology, 4(11), 991-998.

Mutlu E. and Aydin Uncumusaoglu. A. (2017), Investigation of the water quality of Alpsarı Pond (Korgun-Çankırı), Turkish Journal of Fisheries and Aquatic Sciences, 17, 1231-1243.

Ogwueleka T.C. (2015), Use of multivariate statistical techniques for the evaluation of temporal and spatial variations in water quality of the Kaduna River, Nigeria, Environmental Monitoring and Assessment, 187(3), 137. Doi:10.1007/s10661-015-4354-4.

Omo-Irabor O.O., Olobaniyi S.B., Oduyemi K. and Akunna J. (2008), Surface and ground water quality assessment using multivariate analytical methods: a case study of the Western Niger Delta, Nigeria, Phys Chem Earth, 33, 663- 673.

Ouyang Y. (2005), Evaluation of river water quality monitoring stations by principal component analysis, Water Res., 39(12), 2621.

Özdemir Ö. (2016), Application of multivariate statistical methods for water quality assessment of Karasu-Sarmisakli Creeks and Kizilirmak River in Kayseri, Turkey, Polish Journal of Environmental Studies, 25(3), 1149-1160.

Şengül Ü. (2016), Comparing determination methods of detection and quantification limits for aflatoxin analysis in hazelnut, Journal of Food and Drug Analysis, 24(1), 56-62. doi:10.1016/j.jfda.2015.04.009.

Shrestha S. and Kazama F. (2007), Assessment of surface water quality using multivariate statistical techniques: A case study of the Fuji River Basin, Japan. Environmental Modelling and Software, 22(4), 464-475.

Simeonov V., Stratis J.A., Samara C., Zachariadis G., Voutsa D., Anthemidis A., Sofoniou M. and Kouimtzis T. (2003), Assessment of the surface water quality in Northern Greece, Water Research, 37(17), 4119-4124.

Singh K.P., Malik A., Mohan D. and Sinha S. (2004), Multivariate statistical techniques for the evaluation of spatial and temporal variations in water quality of Gomti River (India)-a case study, Water Res., 38, 3980-3992.

SWQMR. (2015). Regulation on the surface water quality management. Number of official gazette: 29327.

(URL, 2014). http://www.boyabatsonhaber.com/haber/2030aktuel-goletlere-3000-adet-balik-birakildi.html 14.08 .2014).

WHO, (2011). Guidelines for Drinking Water Quality, 4th Ed., Geneva, Switzerland: WHO.

Wu M.L., Wang Y.S., Sun C.C., Wang H.L., Dong J.D., Yin J.P. and Han S.H. (2010), Identification of coastal water quality by statistical analysis methods in Daya Bay, South China Sea, Marine Pollut Bull, 60, 852-860.

Wunderlin D.A., Díaz M.P., Amé M.V., Pesce S.F., Hued A.C. and Bistoni M.A. (2001), Pattern recognition techniques for the evaluation of spatial and temporal variations in water quality. A case study: Suquía River Basin (Córdoba-Argentina), Water Research, 35(12), 2881-2894.

Yang Y.H., Zhou F., Guo H.C., Sheng H., Liu H., Dao X. and He C.J. (2010), Analysis of spatial and temporal water pollution patterns in Lake Dianchi using multivariate statistical methods, Environmental Monitoring and Assessment, 170(1-4), 407-416. https://doi.org/10.1007/s10661-009$1242-9$
Zhaoa Y., Xia X.H., Yang Z.F. and Wang F. (2012), Assessment of water quality in Baiyangdian Lake using multivariate statistical techniques, Procedia Environmental Sciences, 13, 1213-1226. 